\title{
Interest rate development as an indicator of credit market integration
}

\section{Jan Černohorský}

Faculty of Economics and Administration, Institute of Economic Sciences,

University of Pardubice,

532 10, The Czech Republic

Email: jan.cernohorsky@upce.cz

\begin{abstract}
The goal of this paper is to evaluate the development of credit market integration in selected European Union countries on the basis of an analysis of the development of lending and deposit interest rates. We began with the values of the nominal lending and deposit interest rates. For this, we have used existing interest rate differentials in selected European countries calculated as the difference between the given rate in a specific country and the average of the given rate in the European Monetary Union. We judged their relationships using the mathematical-statistical method of single-factor analysis of variance (ANOVA). For deposit interest rates, the degree of integration did not show any distinct changes; for lending interest rates, the degree of integration decreased slightly. We proved that the method used in this paper is able to assess not only the degree of credit market integration but also of financial markets as a whole.
\end{abstract}

Keywords: credit markets; integration; lending interest rate; deposit interest rate.

Reference to this paper should be made as follows: Černohorský, J. (xxxx) 'Interest rate development as an indicator of credit market integration', Int. J. Monetary Economics and Finance, Vol. x, No. x, pp.xxx-xxx.

Biographical notes: Jan Černohorský works as a Lecturer at the University of Pardubice, Faculty of Economics and Administration since 2002. He is mainly engaged in finance, banking and monetary policy in its scientific and educational work. He lectured at domestic and international conferences and universities.

\section{Introduction}

A high level of integration for credit markets (as part of financial markets) is an indisputable condition for integration within the European Monetary Union. Due to more effective capital allocation, financial integration helps to achieve a greater level of economic growth for a country, a more effective banking system and even increased pressure for implementing fiscal and monetary policies. Therefore, analysis of credit market integration is currently of considerable interest to scientists, analysts and creators of economic policy. 


\section{Theoretical background}

Currently, three primary methods for measuring credit market integration are prevalent: methods based on price indicators, quantitative indicators and indicators based on new information. The following methods are described in more detail by Adam et al. (2002), Baele et al. (2004), Pungulescu (2009) and Vodová (2010), for example.

Financial markets are considered to be integrated when

- all potential market participants with the same typical characteristics face the same rules when they decide to utilise financial tools or services

- they have direct access to the above-mentioned financial tools or services

- they are considered equal when conducting their activities (Baele et al., 2004).

In this paper, we use the definition given by Adam et al. as a starting point; it defines integrated markets as markets where the law of one price holds. This means that homogeneous financial assets are assessed on the financial markets with one price, irrespective of their place of sale. Vodová (2011) comes close to this definition for credit markets; she states that credit markets are integrated if the conditions under which potential borrowers (households or firms) are able to acquire credit are not influenced by the bank's geographic location.

The development of credit market integration was also studied by Rughoo and Sarantis (2012), who saw significant integrative development in the area of lending rates to non-financial corporations up to the outbreak of the financial crisis. According to them, the null of convergence appeared on the credit market after this. Furthermore, the specific situation differs according to individual regions. The perspective that a greater degree of integration is primarily reflected in the long-term credit market - with a definite time delay after the adoption of the euro - is also supported by European Central Bank studies (2014), which showed that the greatest integration was achieved for long-term instruments, i.e., home mortgage loans. On the contrary, the integration process was not proved for short-term loans. Furthermore, Dell'Ariccia and Marquez (2006) studied the relationship of independent central regulators and credit market integration and came to the conclusion that partial or multilateral agreements between countries prevent a greater financial integration between countries. Černohorský and Kynclová (2014) also analyse the influence of the financial crisis on the integration of credit markets as part of financial markets. Černohorská et al. (2009) examine the results of the financial crisis on the world financial markets in detail, Černohorský (2014) deals with the concrete influence on credit markets measured by nominal lending rates. He comes to the conclusion that the financial crisis had a slightly negative influence on credit market integration - measured by average nominal lending rates.

On the basis of what has been written above, the goal of this paper is to evaluate the development of credit market integration in selected European Union countries on the basis of an analysis of the development of lending and deposit interest rates. We will measure the degree of integration that has been attained by observing the convergence of the price indicators for the same assets in various countries - specifically, of the differentials for nominal lending and deposit interest rates. 


\section{Data}

In the next section, we began with the values of the nominal lending and deposit interest rates published by the International Monetary Fund. We calculated the differentials as the difference between these values in the given countries and the average lending or deposit interest rates in the Eurozone. Beginning in 2012, all the values for the given rates are not available for all the countries analysed; therefore, the data are from the years 2005-2011. Tables 1 and 2 show the development of interest differentials for the nominal lending and nominal deposit interest rates. Negative values means that interest rates in the given countries were lower than the Eurozone average, and positive values mean that the interest rates were higher than the Eurozone average.

Table 1 The development of the nominal deposit interest rate differential for the period 2005-2011 (\% p.a.)

\begin{tabular}{lrrrrrrr}
\hline Country & 2005 & \multicolumn{1}{c}{2006} & 2007 & 2008 & 2009 & 2010 & 2011 \\
\hline Austria & -0.02 & 0.06 & 0.07 & -0.07 & -0.45 & -1.03 & -0.96 \\
Belgium & -0.03 & -0.01 & 0.05 & -0.21 & -0.83 & -1.34 & -1.43 \\
Bulgaria & 1.10 & 0.50 & -0.11 & 0.10 & 4.17 & 1.97 & 0.76 \\
Czech Republic & -0.81 & -1.48 & -2.47 & -2.73 & -0.74 & -1.03 & -1.57 \\
Estonia & 0.15 & 0.17 & 0.58 & 1.38 & 2.81 & -1.00 & -1.34 \\
Finland & 0.08 & 0.25 & 0.33 & 0.20 & -0.55 & -0.59 & -0.61 \\
France & 0.17 & 0.09 & -0.02 & -0.17 & -0.33 & -0.51 & -0.51 \\
Germany & -0.07 & -0.06 & -0.04 & -0.21 & -0.63 & -1.01 & -1.19 \\
Greece & 0.25 & 0.19 & 0.16 & 0.53 & 0.73 & 1.14 & 1.56 \\
Hungary & 3.19 & 4.78 & 3.02 & 5.58 & 3.81 & 2.81 & 3.58 \\
Ireland & 0.02 & -0.03 & 0.02 & 0.14 & 1.60 & 0.82 & 0.56 \\
Italy & -0.53 & -1.02 & -1.54 & -1.55 & 0.01 & -0.78 & -0.64 \\
Latvia & 0.80 & 0.86 & 2.27 & 2.00 & 6.03 & -0.24 & -2.10 \\
Luxembourg & -0.04 & -0.10 & -0.20 & -0.40 & -1.24 & -1.52 & -1.62 \\
Netherland & 0.36 & 0.31 & 0.11 & 0.03 & 0.59 & 0.26 & 0.00 \\
Portugal & -0.11 & -0.17 & -0.12 & -0.13 & -0.02 & -0.40 & 0.91 \\
Romania & 4.44 & 2.10 & 2.91 & 5.17 & 9.98 & 5.20 & 3.69 \\
Spain & 0.09 & 0.08 & 0.09 & 0.29 & 0.47 & 0.30 & 0.01 \\
\hline & Aur & & & & & &
\end{tabular}

Source: Author's calculation based on International Monetary Fund. International Financial Statistics: Yearbook 2012. International Monetary Fund, Washington, DC, 2012

The values of interest rates in each economy indicate its condition. The changes in interest rates are the main factor that moves the currency markets and are a reason so that big investors move their money from one country to another for the purpose of higher returns. The decisive factor influencing the lending interest rate differential is the credibility of the economy and its financial market. The economy is more credible, the more negative differential shows (see, e.g., Luxembourg) and vice versa (see, e.g., Romania, Bulgaria, Greece). Also applies that growth of liquidity in the banking sector 
signifies fall of interest rates. Regarding the development of the values of interest rate differentials, most countries are getting from negative values to positive (states with less credibility withdraw most other states) - this is due to the influence of the financial crisis and growing investor distrust after 2008. Conversely, countries credible in terms of financial markets (e.g., Germany, the Netherlands, Luxembourg) shown either more strongly negative value of differentials or at least this value remained at about the same level. The nominal deposit interest rate differentials take values from both sides closer to zero. The differences are not so significant - this is due to lower impact of risk compared to lending differentials. Here, on the contrary, it plays a larger role the influence of interbank liquidity.

Table 2 The development of the nominal lending interest rate differential for the period 20052011 (\% p.a.)

\begin{tabular}{lrrrrrrr}
\hline Country & 2005 & 2006 & 2007 & 2008 & 2009 & 2010 & 2011 \\
\hline Austria & -1.74 & -1.73 & -1.73 & -1.76 & -2.48 & -1.16 & -0.36 \\
Belgium & -0.42 & -0.68 & -1.05 & -1.55 & -1.37 & -0.12 & 0.61 \\
Bulgaria & 1.92 & 1.65 & 1.97 & 2.28 & 3.82 & 5.24 & 5.26 \\
Czech Republic & -0.96 & -1.65 & -2.24 & -2.33 & -1.53 & -0.01 & 0.35 \\
Estonia & -1.81 & -2.21 & -1.57 & -0.03 & 1.87 & 1.86 & 0.75 \\
Finland & -2.70 & -2.78 & -2.41 & -2.79 & -4.01 & -2.65 & -1.59 \\
France & -1.90 & -1.27 & -0.75 & -0.45 & -0.06 & 0.76 & 0.67 \\
Germany & -1.58 & -1.84 & -2.07 & -2.61 & -2.56 & -2.13 & -1.92 \\
Greece & 1.73 & 0.65 & -0.33 & 0.07 & 1.07 & 3.89 & 4.79 \\
Hungary & 1.80 & 0.84 & 1.06 & 1.60 & 3.52 & 1.69 & 2.95 \\
Ireland & -1.77 & -1.72 & -1.51 & -1.82 & -3.20 & -0.45 & 0.46 \\
Italy & 3.81 & 3.71 & 2.90 & 2.73 & 2.74 & 2.23 & 2.24 \\
Latvia & -0.63 & 0.05 & 2.88 & 3.27 & 8.71 & 3.66 & 1.02 \\
Luxembourg & -3.29 & -3.27 & -3.22 & -3.64 & -4.83 & -3.61 & -3.14 \\
Netherland & 0.56 & 0.70 & 0.68 & 1.08 & 2.49 & -0.15 & -2.16 \\
Portugal & 0.83 & 0.40 & -0.11 & -0.23 & -1.40 & 0.36 & 2.43 \\
Romania & 12.86 & 6.74 & 5.32 & 6.41 & 9.76 & 8.17 & 6.76 \\
Spain & 1.23 & 1.49 & 1.86 & 2.44 & 3.20 & 1.46 & 0.59 \\
\hline & rat & & & & & &
\end{tabular}

Source: Author's calculation based on International Monetary Fund. International Financial Statistics: Yearbook 2012. International Monetary Fund, Washington DC, 2012.

\section{Methods}

In practice, measuring credit market integration is relatively complicated. Standard practice is to use calculations that use $\beta$ - convergence and $\sigma$-convergence and measure integration based on news - see, e.g., Babetskii et al. (2007) for more information. In order to measure integration precisely, it is of key importance to find an asset that has the same degree of risk and generates identical financial flows. As mentioned above, we 
have based our analysis on the law of one price; therefore, we chose the method based on price indicators that have been described in more detail by Adam et al. (2002), Cabral et al. (2002), Vodová (2009) and Pungulescu (2002).

We proceed from the law of one price, because in case of a single monetary union (EMU, where most of the analysed countries are, or where countries are likely to eventually entry) the result should be the same, respectively, very similar valuation of the fundamental financial instruments - in our case the values of nominal interest lending and deposit rates.

We chose the interest differentials for nominal lending and deposit interest rates as the initial price indicators. We selected these as possible indicators for credit market integration precisely because a decrease in interest rate differentials is, according to standard economic findings, one of the basic prerequisites for greater credit market integration.

In the paper, we have decided to use the statistical method of one-factor analysis of variance (ANOVA), which allows us to compare the mean values of several populations. The principle of this method lies in the decomposition of the total sum of deviation squares from the arithmetic mean, calculated from all the measured values on the number of components that belong to the expected sources of variability. These components are mutually compared, and based on their relationships it is possible to make conclusions, whether the total variance was primarily caused due to the differences in the mean values, or as a result of random effects (Kubanová, 2004).

ANOVA was chosen because it allows comparing mean values of independent random selection. So it is a statistical method that helps the economic interpretation of how the mean value of the selection (in our case - differentials lending and deposit rates) diverge from each other.

Thus, ANOVA tests the null hypothesis that all random variables $Y_{i}$ have the same mean values of $\mu_{i}$. If the null hypothesis is rejected, it is necessary to reveal which samples differ significantly from each other, and thus had caused the rejection of the hypothesis. For this purpose, we will use the Scheffe's or Turkey method, because the number of observations in each group is the same.

To ensure that the ANOVA technique can be used, it is necessary to meet the assumptions of normality and homogeneity of variances in populations. In this paper, we will use the Shapiro-Wilk test for testing the normality and Bartlett's test for testing the homogeneity of variances. Both tests are, based on Kubanová (2004), specified below.

Shapiro-Wilk test for normality - By means of this test we test the null hypothesis $\left(H_{0}\right): H_{0}: X$ has $N(\mu, \sigma)$ probability distributions against the alternative hypothesis $H_{1}$ : $X$ does not have $N(\mu, \sigma)$ of probability distributions.

The test criterion is given by:

$$
S W=\frac{\left(\sum_{i=1}^{m} a_{i}(n)\left(X_{(n-i+1)}-X_{(i)}\right)^{2}\right.}{\sum_{i=1}^{n}\left(X_{i}-\bar{X}\right)^{2}},
$$

where $a_{i}(n)$ are tabulated constants, $m=n / 2$, if $n$ is even and $m=(n-1) / 2$, if $n$ is an odd number, $X_{(n-i+1)}$ and $X_{(i)}$ are the order statistics of a random sample $X_{1}, \ldots, X_{n}$ created through its arrangement into a non-decreasing sequence. 
The test principle lies in the fact that we estimate $\sigma$ by the random variable $S^{*}=\sum_{i=1}^{n} a_{i} X_{i}$ and its estimate is compared with an estimate based on the random variable $\sum_{i=1}^{i=1}\left(X_{i}-\bar{X}\right)^{2}$.

Bartlett's test for homogeneity - This test verifies the hypothesis that all samples come from populations with equal variance of $\sigma^{2}$. We are testing the null hypothesis: $H_{0}: \sigma_{1}^{2}=\sigma_{2}^{2}=\cdots=\sigma_{k}^{2}$ against the alternative hypothesis $H_{1}: \sigma_{i}^{2} \neq \sigma_{j}^{2}$ for at least one index pair $i, j$. The test criterion is given by:

$$
B=\frac{1}{C}\left[(n-k) \ln S^{2}-\sum_{i=1}^{k}\left(n_{i}-1\right) \ln {\overline{S_{i}^{2}}}^{2},\right.
$$

where $C$ is an auxiliary factor, $\bar{S}_{i}^{2}$ symbol denotes unbiased estimates of variances $\sigma_{i}^{2}$ in individual samples and $S^{2}$ is the composite sample variance. If at least one of these assumptions is not met, then the one-factor ANOVA technique cannot be applied and we have to use its non-parametric equivalent, which is called the Kruskal-Wallis test.

Kruskal-Wallis test - This test is used for testing the hypothesis that all samples come from the same population, hence all distribution functions $\left(F_{i}, i=1, \ldots, k\right)$ are identical. Then the null hypothesis can be formulated in the following way: $H_{0}$ : $F_{1}(x)=F_{2}(x)=\cdots=F_{k}(x)$ against the alternative hypothesis $H_{1}: F_{i}(x) \neq F_{j}(x)$ for at least one index pair $i \neq j$. The test criterion is given by:

$$
Q=\frac{12}{n(n+1)} \sum_{i=1}^{k} \frac{R_{i}^{2}}{n_{i}}-3(n+1),
$$

where $k$ is the number of levels of the traced factor, $n=n_{1}+n_{2}+\cdots+n_{k}$ is the total sample size, $n_{i}$ is the number of observations in sample $i$ and $R_{i}$ is the sum of element ranks taken from the $i$ th sample.

Upon the rejection of the null hypothesis it is necessary to find out which samples differ significantly from each other and had caused the rejection of the hypothesis. This can be found out by means of multiple comparisons of mean ranks for all groups.

Significance level (Type I error rate $\alpha$ ) has been set at 0.05 in the paper, which means that we obtain $95 \%$ confidence level for the correct decision.

Next, we began the analysis of this data by dividing the data into two periods (2005-2007 and 2008-2011) in order to assess the development of the interest differentials. Then, we analysed first the development of the differential for the nominal deposit rate (in the first and second periods) and then the development of the differential for the nominal lending rate (in the first and second periods) using the selected methods.

\section{Empirical results}

\subsection{Analysis of the deposit rate differential in the first period}

It was not possible to use a single-factor ANOVA to analyse the deposit rate differential in the first period, because the assumption of homogeneity was not met. The assumption of normality was met, because all $p$ values are higher than the selected level of 
significance -0.05 . The results of the test for normality and homogeneity of variance are presented in Tables 3 and 4 .

Table 3 Verification of the assumption of normality of variance for the nominal deposit rate differential in the first period

\begin{tabular}{lclc}
\hline Country & $p$ value & Country & $p$ value \\
\hline Austria & 0.193917 & Hungary & 0.167436 \\
Belgium & 0.463262 & Ireland & 0.363112 \\
Bulgaria & 0.990886 & Italy & 0.967250 \\
Czech Republic & 0.788310 & Latvia & 0.068885 \\
Estonia & 0.078716 & Luxembourg & 0.726225 \\
Finland & 0.608615 & Netherland & 0.363112 \\
France & 0.826375 & Portugal & 0.298275 \\
Germany & 0.636886 & Romania & 0.664223 \\
Greece & 0.636886 & Spain & 0.999999 \\
\hline
\end{tabular}

Source: Author's calculation based on International Monetary Fund. International Financial Statistics: Yearbook 2012. International Monetary Fund, Washington DC, 2012

Table 4 Verification of the assumption of homogeneity of variance for the nominal deposit rate differential in the first period

\begin{tabular}{lcccc}
\hline & \multicolumn{4}{c}{ Tests for homogeneity of variance } \\
\cline { 2 - 5 } & Effect: 'country' \\
\cline { 2 - 5 } & Hartley F-max & Cochran $C$ & Bartlett Ch-sq. & $p$ \\
\hline Rate & $14,121.00$ & 0.31507 & 82.94215 & 0.000000 \\
\hline
\end{tabular}

Source: Author's calculation

The next step was to conduct the Kruskal-Wallis test; its null hypothesis was rejected $(p<0.05)$, which means that there were differences between the deposit rate differentials for the first period that was studied. The results of the Kruskal-Wallis test are presented in the heading of Table 5. Therefore, it was necessary to perform multiple comparisons (see Table 5), which revealed that the rejection of the Kruskal-Wallis test's null hypothesis was caused by four pairs of countries (Romania and the Czech Republic; the Czech Republic and Hungary; Italy and Hungary and Italy and Romania) - these values are marked in grey.

\subsection{Analysis of the deposit rate differential in the second period}

The null hypothesis of the Shapiro-Wilk test of normality was rejected - see Table 6 (the $p$ value for Finland is smaller than 0.05 ); therefore, it was also impossible to use ANOVA for the second period of the indicators being studied. 
Table 5 Multiple comparison for deposit rate differentials in the first period

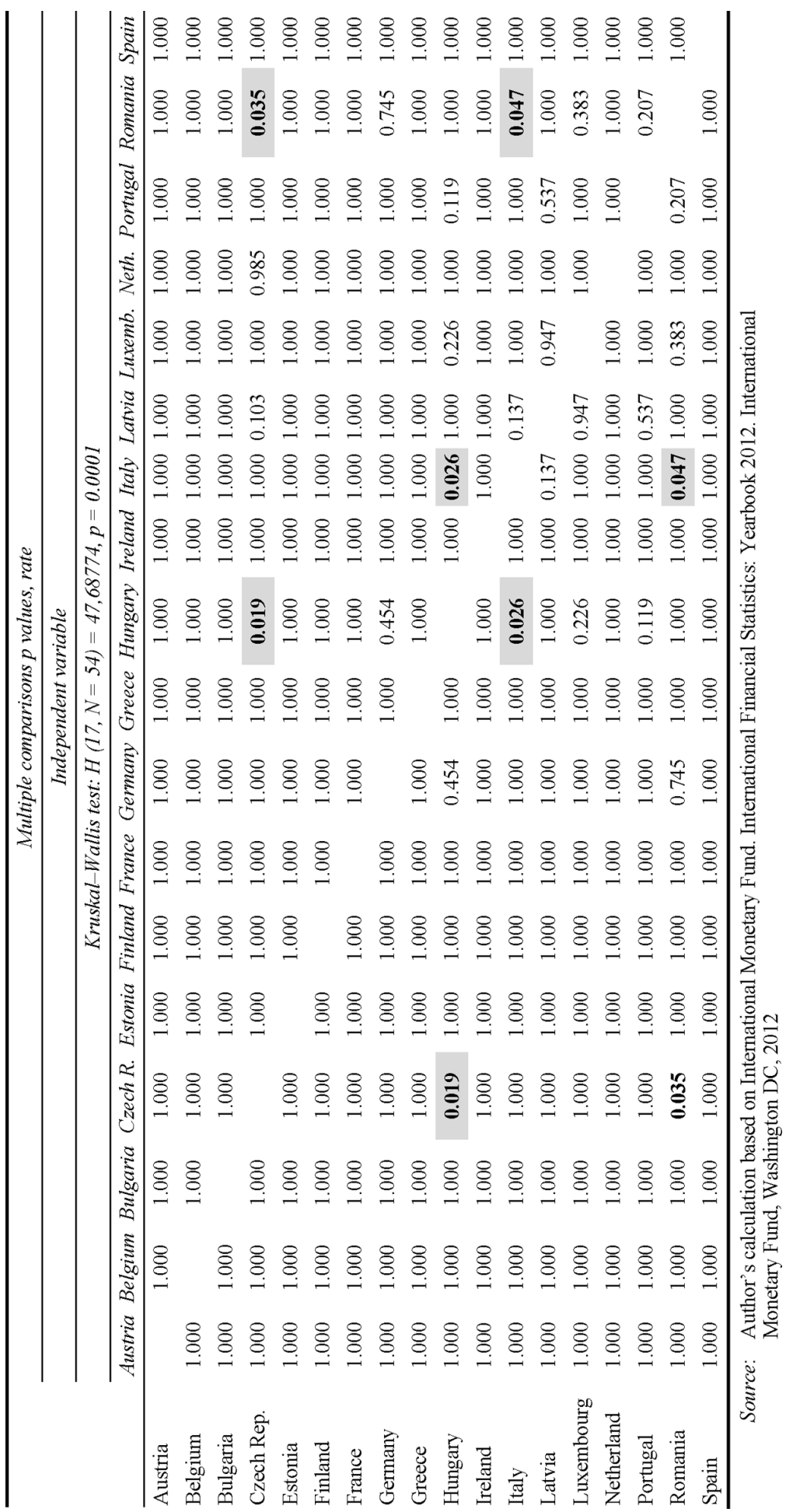


Therefore, its non-parametric equivalent, the Kruskal-Wallis test, was used once again. The null hypothesis of this test was rejected on the basis of a very low $p$ value, which was lower than $\alpha$. Next, multiple comparison was performed; its results are presented in Table 7. As is evident from the table, four pairs of countries (see the values in grey) caused this, the same as for the first period studied.

If we then compare Tables 5 and 7, we can state that the level of credit market integration in the period studied did not change in any way, i.e., it did not increase or decrease. This is because, on the basis of the non-parametric Kruskal-Wallis test that was conducted, there is the same amount of country pairs with a statistically significant difference in the middle values for the deposit rate differentials.

Table 6 Verification of the assumption of normality for nominal deposit rate differentials in the second period

\begin{tabular}{llll}
\hline Country & $p$ value & Country & $p$ value \\
\hline Austria & 0.439587 & Hungary & 0.519934 \\
Belgium & 0.444028 & Ireland & 0.827450 \\
Bulgaria & 0.628886 & Italy & 0.874611 \\
Czech Republic & 0.523406 & Latvia & 0.822824 \\
Estonia & 0.424009 & Luxembourg & 0.229823 \\
Finland & 0.008062 & Netherland & 0.351590 \\
France & 0.275937 & Portugal & 0.287097 \\
Germany & 0.763791 & Romania & 0.173838 \\
Greece & 0.786584 & Spain & 0.580768 \\
\hline
\end{tabular}

Source: Author's calculation based on International Monetary Fund. International Financial Statistics: Yearbook 2012. International Monetary Fund, Washington DC, 2012

\subsection{Analysis of the lending rate differential in the first period}

It was not possible to use ANOVA to analyse the second indicator of credit market integration that was selected, i.e., lending rate differentials for selected EU countries in the first period, because the assumption of homogeneity of variance was not met $(p<0.05)$. The results of this test and the test of normality, which was met, are presented in Tables 8 and 9.

After conducting the Kruskal-Wallis test, whose null hypothesis was rejected $(p<0.05$ - see the heading of Table 10), multiple comparison was performed (see Table 10). It is evident from the table, that three pairs of countries showed lending rate differentials different enough to cause the rejection of the Kruskal-Wallis test's null hypothesis. Specifically, these were the pairs of Romania and Finland; Romania and Luxembourg; and Italy and Luxembourg (grey values).

\subsection{Analysis of the lending rate differential in the second period}

In order for us to say whether or not credit market integration increased according to the lending rate differentials, it is necessary to analyse this indicator in the second period as well. The Kruskal-Wallis test was used, because the assumption of normality was not met - the $p$ value for Italy was less than 0.05 (see Table 11). 
Table 7 Multiple comparison for deposit rate differentials in the second period

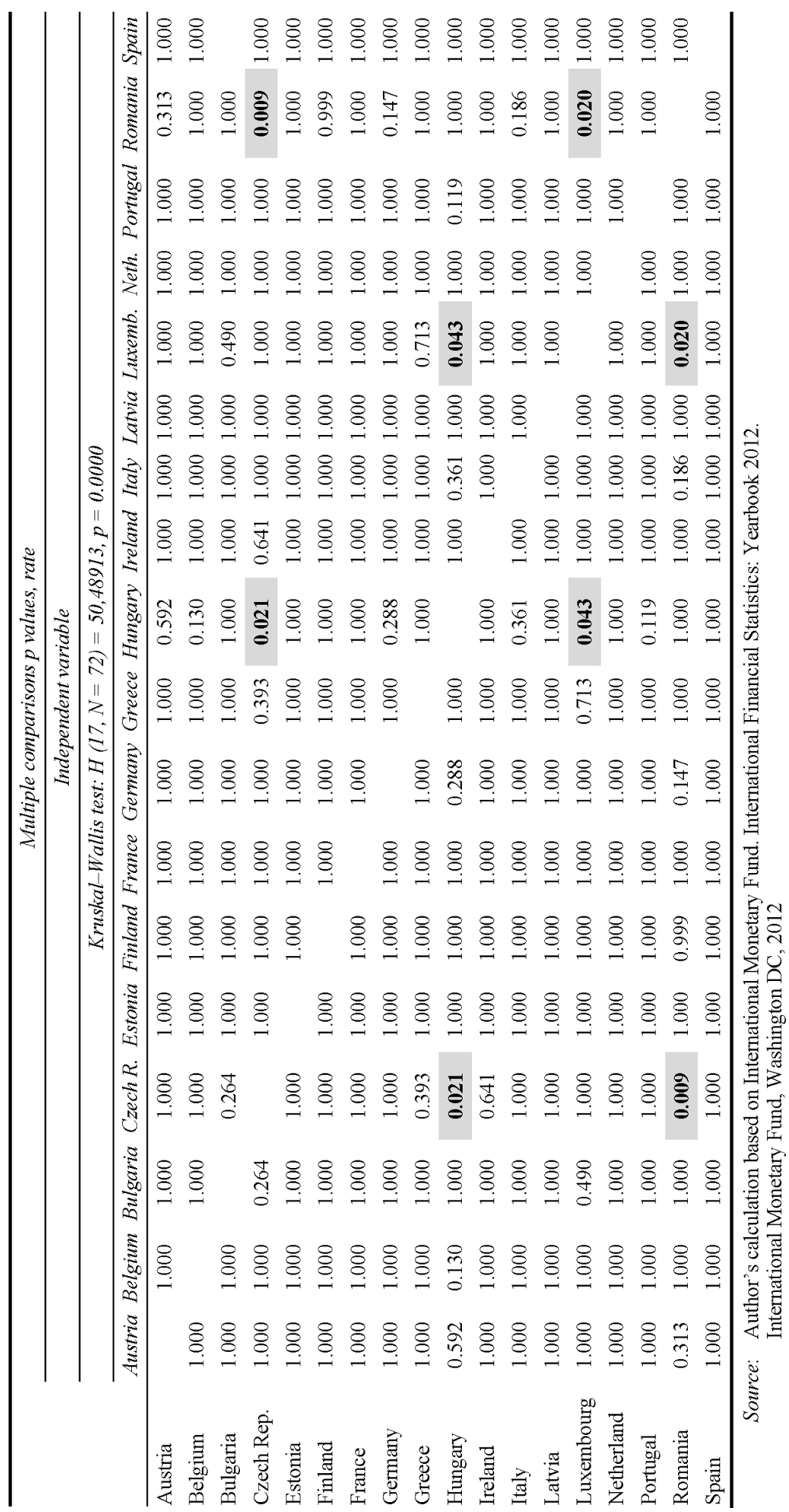


Table 8 Verification of the assumption of normality of variance for nominal lending rate differentials in the first period

\begin{tabular}{lclc}
\hline Country & $p$ value & Country & $p$ value \\
\hline Austria & 0.999999 & Hungary & 0.421129 \\
Belgium & 0.808120 & Ireland & 0.348008 \\
Bulgaria & 0.278348 & Italy & 0.191677 \\
Czech Republic & 0.913912 & Latvia & 0.350798 \\
Estonia & 0.726225 & Luxembourg & 0.536736 \\
Finland & 0.395225 & Netherland & 0.252969 \\
France & 0.894634 & Portugal & 0.906231 \\
Germany & 0.932517 & Romania & 0.340228 \\
Greece & 0.946486 & Spain & 0.808120 \\
\hline
\end{tabular}

Source: Author's calculation based on International Monetary Fund. International Financial Statistics: Yearbook 2012. International Monetary Fund, Washington DC, 2012

Table 9 Verification of the assumption of homogeneity of variance for nominal lending rate differentials in the first period

\begin{tabular}{lcccc}
\hline \multicolumn{4}{c}{ Tests for homogeneity of variance } \\
\cline { 2 - 5 } & Cochran C & Bartlett Ch-sq. & $p$ \\
\cline { 2 - 5 } & Hartley F-max & 0.713342 & 81.04175 & 0.000000 \\
\hline Rate & $160,537.3$ & Effect: 'country' \\
\hline
\end{tabular}

Source: Author's calculation based on International Monetary Fund. International Financial Statistics: Yearbook 2012. International Monetary Fund, Washington DC, 2012

Because the Kruskal-Wallis test's null hypothesis was rejected $(p<0.05)$, it is thus possible to say that a difference in lending rate differentials does exist between individual countries. Multiple comparison, whose results are presented in Table 12, revealed that the differentials differed for six pairs of EU countries - the given values are again marked in grey.

Thus, if we compare Tables 10 and 12, we can state that the degree of credit market integration in the second period was slightly lower than the first period. This is because, on the basis of the non-parametric Kruskal-Wallis test that was conducted, there are more pairs of countries that show a statistically significant difference in the middle values for the lending rate differentials.

\section{Discussion}

We came to the conclusion that the level of integration for deposit interest rates did not undergo any significant changes and that the degree of integration for lending interest rates decreased slightly. 
Table 10 Multiple comparison for lending rate differentials in the first period

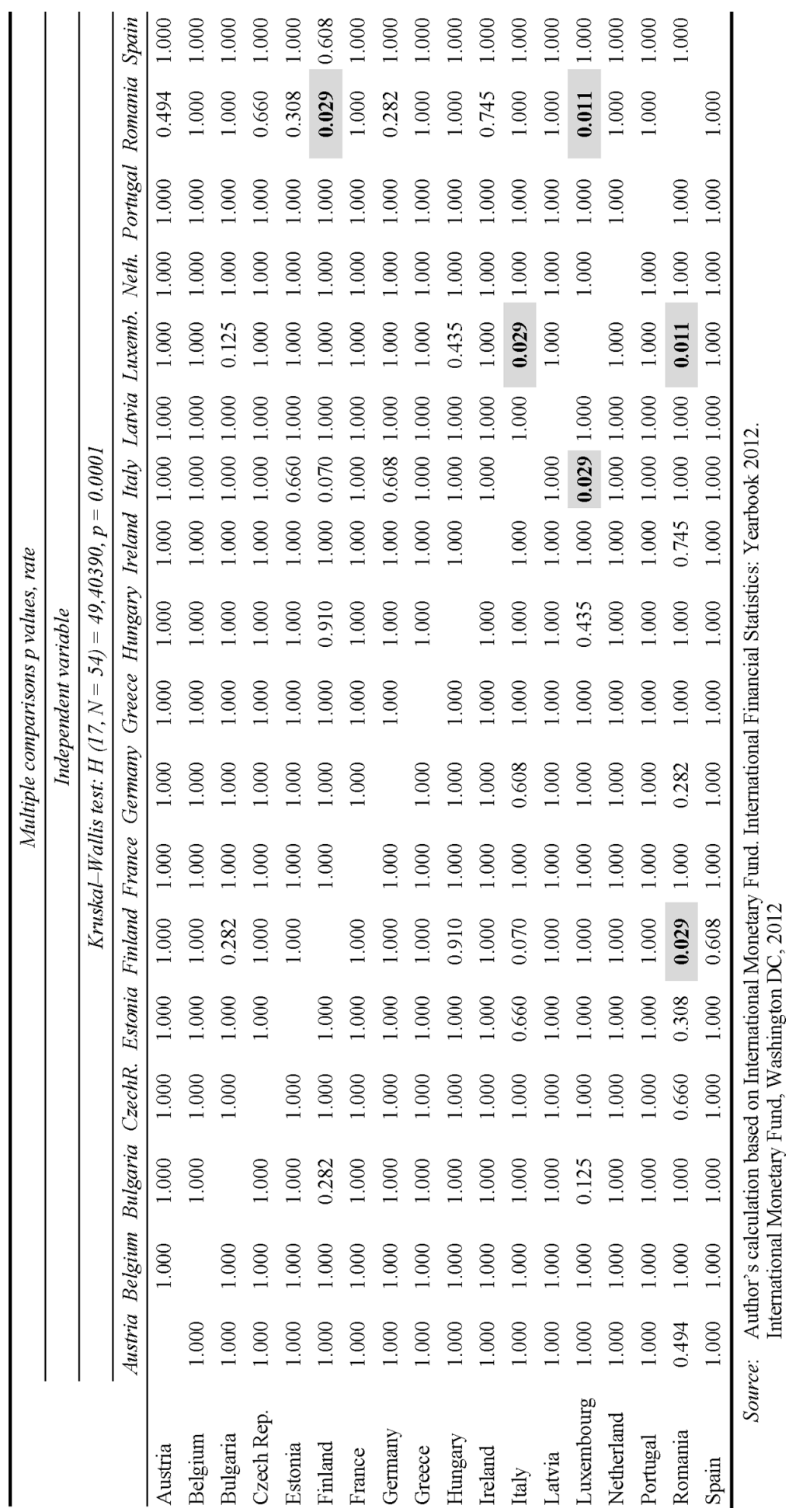


Table 11 Verification of the assumption of normality of variance for nominal lending rate differentials in the second period

\begin{tabular}{lclc}
\hline Country & $p$ value & Country & $p$ value \\
\hline Austria & 0.993181 & Hungary & 0.288956 \\
Belgium & 0.421082 & Ireland & 0.892713 \\
Bulgaria & 0.281817 & Italy & 0.035590 \\
Czech Republic & 0.509887 & Latvia & 0.459586 \\
Estonia & 0.277026 & Luxembourg & 0.310695 \\
Finland & 0.816323 & Netherland & 0.966683 \\
France & 0.381063 & Portugal & 0.821477 \\
Germany & 0.356123 & Romania & 0.541113 \\
Greece & 0.492537 & Spain & 0.927799 \\
\hline
\end{tabular}

Source: Author's calculation based on International Monetary Fund. International Financial Statistics: Yearbook 2012. International Monetary Fund, Washington DC, 2012

This can be explained economically that the influence of increased distrust of investors has no effect in case of deposit interest rates, but rather the influence of expansionary monetary policy in response to the financial crisis, which thus keeps the degree of integration at a similar level. The increase of differentials in the case of lending interest rates (it means lower degree of integration) can be explained by a growing distrust of investors in the analysed period, higher market volatility and economic imbalance between eastern and western European countries. Just some eastern European countries have the highest value of differentials. This can be attributed to the lack of economic performance in addition to local factors like untrustworthy fiscal policy, significant changes in the tax system and problems with repayment of previously granted loans, etc.

The European Central Bank (2014) and the Czech National Bank (2011) also came to similar conclusions in their studies. The European Central Bank states in summary that the greatest level of integration was attained by long-term instruments, i.e., home mortgage loans. Conversely, the integration process was not established for short-term loans. For consumer loans, however, there were obvious symptoms of disintegration. The Czech National Bank (2011) came to the conclusion that the degree of credit market integration was increasing before 2008. From this year on, however, development tended to diverge from this trend; the markets were more volatile and the situation began to calm down only half way through 2009. Vodová (2011) also comes to a similar conclusion in her study; she examines credit market integration on the basis of quantitative indicators. Vodová states that the degree of credit integration in the European Union is increasing but that it has slowed down as a result of the financial crisis (i.e., during the same years that were examined). When Vodová used price indicators (2012), she concluded that the speed and degree of convergence varied according to segment and country. Jappelli and Pagano (2008) presented conclusions concerning a decrease in the level of financial market integration in recent years (measured, however, on the bond markets). According to their calculations, the standard deviation for the yield of government bonds has increased by more than one-third in recent years. According to Pungulescu (2009), integration has not yet been completed, primarily for the majority of Eastern European countries. Conversely, developed economies show signs of having high levels of 
financial market integration. This also corresponds with our conclusions, because there was at least one Eastern European country in each test that caused the rejection of the hypothesis about integrated markets. Again, integration varies within the European Union according to market segment, and local factors are constantly at work here. Baltzer et al. (2008) demonstrate a greater credit market integration as measured by quantitative indicators, because a country tends to hold a large percentage of bonds from other countries. He further states that it is evident that the differences between short-term, mid-term and long-term interest rates for companies decreased, as did interest rates for household loans and deposits. Nevertheless, he has not dealt with their development for the following years during and after the financial crisis. From this paper and from papers that emerged during and after the financial crisis, negative results from the financial crisis on financial market integration are more likely to be observed. Černohorská et al. (2009), for example, show this in more detail. Based on the discussion of results and comparisons we can conclude that the method ANOVA can be used to assess the degree of integration of financial markets as a whole and its individual parts.

\section{Conclusion}

The goal of this paper was to evaluate the development of credit market integration in selected European Union countries on the basis of an analysis of the development of lending and deposit interest rates.

We began with the values of the nominal lending and deposit interest rates published by the International Monetary Fund. These rates are basic interest rates in each economy which are set by central banks. We measured the level of integration attained using the convergence of price indicators for the same assets in various countries - specifically, nominal lending and deposit interest rate differentials. On the basis of the results, it is possible to state that credit market integration decreased slightly over the monitored period, which is proved mainly by the examination of the development of the interest rate differential for lending interest rates. According to our measurements, credit markets are quite extensively integrated. Nonetheless, the interest rates we examined - in addition to other price and quantitative indicators - need to converge more in the future in order for the financial markets to contribute to greater integration of the European Union as a whole.

It is primarily necessary to reduce the level of distrust of investors for higher convergence of financial markets in Europe. This can be achieved by economical and effective fiscal policy (a significant long-term reduction of state budget deficits), cooperation of monetary and fiscal policies, structural reforms in the most problematic countries (some eastern European countries, Greece, Portugal). The impact of inflation is currently negligible, because inflation is slightly above zero in most countries. However, the price convergence of the less developed countries will be necessary again in the future. This means that these countries will have a higher inflation rate than the developed western European countries. Central banks should not slow down this natural development. We can therefore assume slightly positive interest rate differentials in eastern European countries. It is also clear that the next crisis (of some part of the financial markets) occurs again and it is therefore necessary to set such conditions and stabilise the economy so that the impact of these crises has been minimised. 
Table 12 Multiple comparison for lending rate differentials in the second period

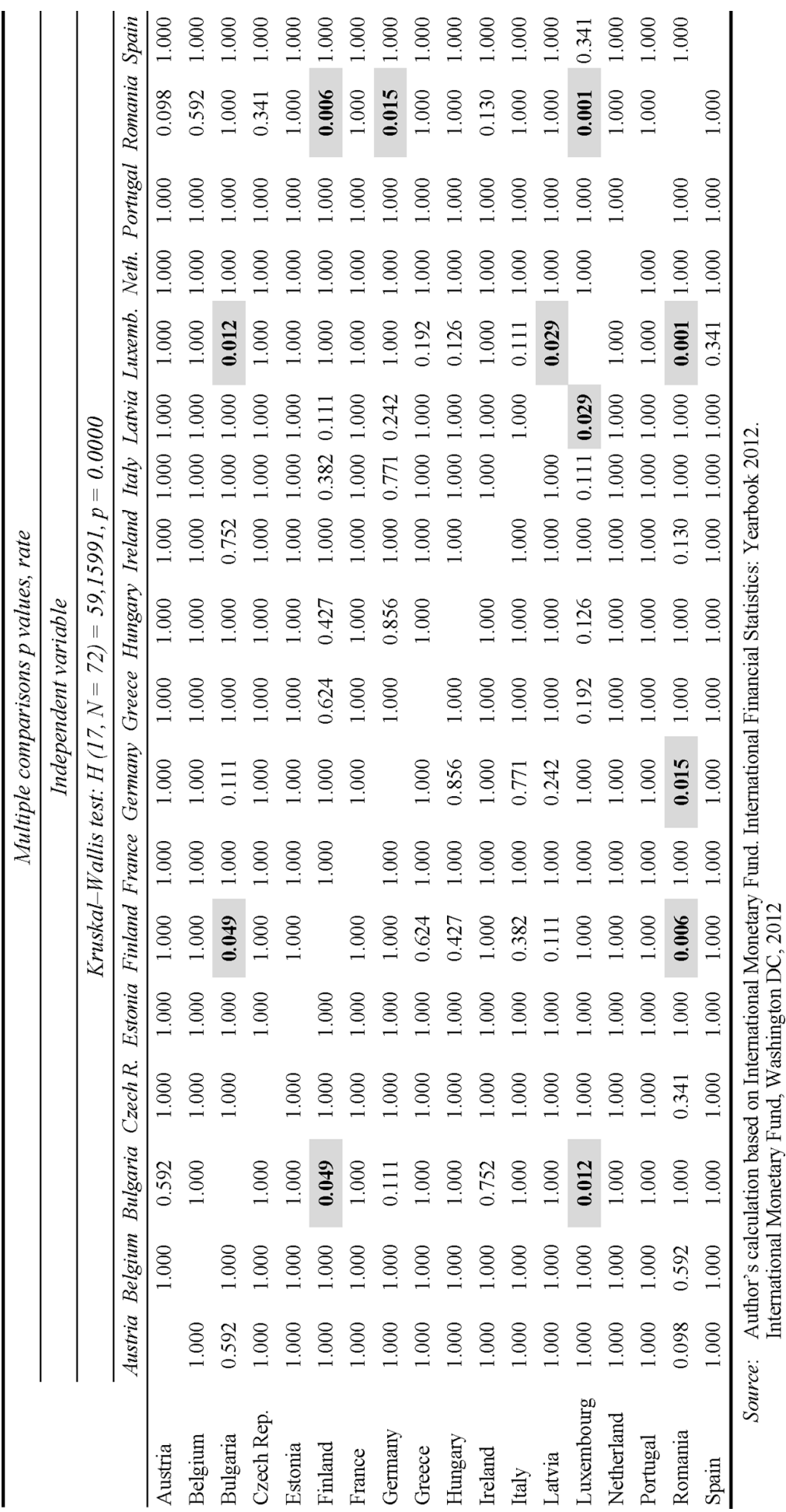




\section{Acknowledgements}

The paper has been created with the financial support of Czech Science Foundation, project no. GA P403/10/1235. The Institutional Responses to Financial Market Failures.

\section{References}

Adam, K., Jappelli, T., Menichini, A., Padula, M. and Pagano, M. (2002) Analyse, Compare and Apply Alternative Indicators and Monitoring Methodologies to Measure the Evolution of Capital Market Integration in the European Union, University of Salerno, Centre for Studies in Economics and Finance, Salerno, http://www.fh-brandenburg.de/ brasche/EU/k2/k23/ k234/cap_mark_int_en.pdf(Accessed 15 August, 2013).

Babetskii, I., Luboš, K. and Zlatuše, K. (2007) Financial Integration of Stock Markets among New EU Member States and the Euro Area, Czech National Bank.

Baele, L., Ferrando, A., Hördahl, P., Krylova, E. and Monnet, C. (2004) Measuring Financial Integration in the Euro Area, ECB Occasional Paper Series, No. 14. Frankfurt am Main: European Central bank, http://www.ecb.europa.eu/pub/pdf/scpops/ecbocp14.pdf (Accessed 14 August, 2013).

Baltzer, M., Cappiello, L., De Santis, R. and Manganelli, S. (2008) Measuring Financial Integration in New EU Member States, ECB Occasional Paper Series No. 81, Frankfurt am Main: European Central bank, http://www.ecb.europa.eu/pub/pdf/scpops/ecbocp81.pdf (Accessed 16 August, 2014).

Cabral, I., Dierick, F. and Vesala, J. (2002) Banking Integration in the Euro Area, European Central Bank, Frankfurt am Main, https://www.ecb.europa.eu/pub/pdf/scpops/ecbocp6.pdf (Accessed 8 August, 2013).

Černohorská, L., Černohorský, J. and Teplý, P. (2009) Implications of the 2008 Financial Crisis for World Financial Markets, Scientific Papers of the University of Pardubice, Series D. 14, pp.13-26.

Černohorský, J. (2014) 'The integration of credit markets', in Čulík, M. (Ed.): Proceedings of the 7th International Scientific Conference Managing and Modelling of Financial Risks, Technical University ofOstrava, Ostrava, pp.127-135, ISBN 978-80-248-3631-7.

Černohorský, J. and Kynclová, L. (2014) 'The impact of the financial crisis on integration of bond markets in the European Union', in Stavárek, D. and Vodová, P. (Eds.): Proceedings of the 14th International Conference on Finance and Banking, Silesian University, Karviná, pp.51-60, ISBN 978-80-7248-939-8.

Dell'Ariccia, G. and Marquez, R. (2006) 'Competition among regulators and credit market integration', Journal of Financial Economics, Vol. 79, No. 2, pp.401-430.

European Central Bank (2014) Financial Integration in Europe, Frankfurt am Main, European Central Bank, http://www.ecb.europa.eu/pub/pdf/other/financialintegrationineurope201404en. pdf (Accessed 3 July, 2014).

Jappelli, T. and Pagano, M. (2008) Financial Market Integration under EMU, Centre for Studies in Economics and Finance Working Paper No. 197, University of Salerno, Salerno, http://www.csef.it/WP/wp197.pdf (Accessed 16 August, 2014).

Kubanová, J. (2004) Statistické Metody Pro Ekonomickou a Technickou Praxi, Statis, Bratislava.

Pungulescu, C. (2002) Measuring Financial Market Integration: An Application for the EastEuropean New Member States, Tilburg University, Tilburg, http://papers.ssrn.com/sol3/ papers.cfm?abstract_id=1271891 (Accessed 4 July, 2015).

Pungulescu, C. (2009) Essays on Financial Market Integration, Tilburg University Press, Tilburg.

Rughoo, A. and Sarantis, B. (2012) 'Integration in European retail banking: evidence from savings and lending rates to non-financial corporations', Journal of International Financial Markets, Institutions and Money, Vol. 22, No. 5, pp.1307-1327, ISSN 1042-4431. 
Vodová, P. (2010) 'Credit market integration and its measuring', Proceedings of the 12th International Conference on Finance and Banking, 28-29 October, Ostravice, The Czech Republic, OPF SLU v Karviné, Karviná.

Vodová, P. (2011) 'Quantity indicators as a measure of credit market integration in the Visegrad countries', Acta Academica Karviniensia, Vol. 14, No. 3, pp.158-165.

Vodová, P. (2012) 'Price indicators as a measure of credit market integration in the visegrad countries', Romanian Journal of Economic Forecasting, Vol. 15, No. 1, pp.62-73. 